TAPROBANICA, ISSN 1800-427X. April, 2010. Vol. 02, No. 01: pp. 48-63, pls. 2.

(C) Taprobanica Nature Conservation Society, 146, Kendalanda, Homagama, Sri Lanka.

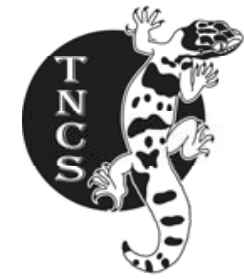

\title{
CURRENT STATUS OF FAUNAL DIVERSITY IN BELLANWILA - ATTIDIYA SANCTUARY, COLOMBO DISTRICT - SRI LANKA
}

D. M. S. Suranjan Karunarathna ${ }^{1,4}$, A. A. Thasun Amarasinghe ${ }^{2,5}$, Dinesh E. Gabadage ${ }^{2}$ Mohomed M. Bahir ${ }^{2}$ and Lee E. Harding ${ }^{3}$

\footnotetext{
${ }^{1}$ Nature Exploration \& Education Team, B-1/G-6, De Soysapura Flats, Moratuwa 10400, Sri Lanka

2 Taprobanica Nature Conservation Society, 146, Kendalanda, Homagama, Sri Lanka

${ }^{3}$ SciWrite Environmental Sciences Ltd. 2339 Sumpter Drive, Coquitlam, British Columbia, Canada

Corresponding authors: ${ }^{4}$ dmsameera@gmail.com, ${ }^{5}$ aathasun@gmail.com
}

\begin{abstract}
The present survey shows the biodiversity decline in Bellanwila - Attidiya Sanctuary (BAS). A total of 152 species of vertebrates and 75 species of butterflies are recorded from BAS. Sixteen of these species are endemic, and five of them are nationally threatened. Vertebrates represent 11 amphibians, 27 reptiles, 22 fresh water fishes, 78 birds and 14 mammal species. Habitat destruction, industrial toxic waste and garbage dumping are the major threats to the biota of the BAS.
\end{abstract}

Key wards: Wetland, Biodiversity decline, Threats, Endangered species, Colombo, Conservation

\section{Introduction}

Sri Lanka is not isolated from the current global period of mass extinctions (Achard et al., 2002; Jenkins, 2003). Many species of animals, plants and other organisms are disappearing by the direct or indirect human activities in the planet: deforestation (Brook, et al., 2003; Ferraz et al., 2003; Pethiyagoda, 2005, 2007a), global warming (Alfred et al., 2007; Harvell et al., 2002; Rosa et al., 2007), invasive alien species (Elton, 1958). Pollution (MacNeely, 1992), fire (Batuwita \& Bahir, 2005;
Swinbanks, 1997), erosion (Hewawasam et al., 2003), agro chemical use (Hayes et al., 2002; Pethiyagoda, 1994), infectious diseases (Daszak et al., 2000; Pounds et al., 2006) and lack of systematic or scientific understanding (Pethiyagoda, 2007b; Bahir, 2009; Bahir \& Gabadage, 2009a,b).

Already in Sri Lanka, known extinctions include many plants and trees (Pethiyagoda, 2005), twentyone amphibian species (Stuart et al., 2004; Manamendra-Arachchi \& Pethiyagoda 2005; 
Meegaskumbura et al., 2007) and two freshwater fish extinctions from Sri Lanka (Pethiyagoda, 1994; Pethiyagoda et al., 2008b).

Because of the paucity of biological inventory in many regions of the country, other extinctions may have gone unnoticed. Indeed, since new species are still being described, it is possible that some species may go extinct before becoming known to science. It is alarming that human population density in our biologically richest wet zone is one of the highest on earth. Also, the population is growing more rapidly than average around protected areas (Wittemyer et al., 2008), a trend that seriously threatens the remaining biodiversity trapped in forest reserves and this is perhaps true for Sri Lanka. Although the Western Ghats and Sri Lanka is a biodiversity hotspot for conservation priorities (Myers et al., 2000; Mittermyer et al., 2004), unfortunately it is one of the most populous identified (Cincotta et al., 2000). Recent research highlighted the uniqueness of the Sri Lankan fauna from the mainland (Bossuyt at al., 2004; Bossuyt et al., 2005; Helgen \& Groves, 2005). Therefore, we need to conserve and protect our natural wealth more aggressively than we have so far.

Several Sri Lankan animal and plant taxa not only contain assemblages of endemics, but these sometimes constitute old branches or distinct clades of the tree of life (Bossuyt et al., 2004; Roelants et al., 2004). This is significant because radiations of tens of species are found exclusively on Sri Lanka (Bossuyt et al., 2005; Gunawardene et al., 2007; Helgen \& Groves, 2005; Meegaskumbura et al., 2002). Therefore, conservation managers could treat these clades of animals and plants as the island's major natural treasure (Bossuyt et al., 2005). Protecting these endemic taxa as "umbrella species" would result in protection of other rare and endangered species. It is in that perspective noteworthy that Sri Lanka's diversity largely restricted to the formerly rain-forested southwestern wet zone, knuckles mountains and the central hills where only a little natural forest with many of the endemics now survive, beset by invasive alien species of plants and surrounded by plantations and settlements. The threats to the unique biodiversity recognized and the challenges to its conservation are therefore formidable and demand urgent international and national level scientific attention, policy and planning. It is our own responsibility to conserve our natural heritage without any delay.
Sri Lanka has various wetland ecosystems, both natural and man-made, that support its biodiversity (Bambaradeniya, 2002). The importance of conservation of wetland ecosystem is recognized globally. Wetland habitats are highly productive and diverse communities that lie between terrestrial and aquatic environments (Goonatilake et al., 2001). Wetlands in Sri Lanka, covering 274, 000 ha, may be categorized as; inland freshwater wetlands (rivers, streams, marshes, swamp forest, villus), saltwater wetlands (lagoons, estuaries, mangroves, sea grass beds, coral reefs), man-made wetlands (tanks, reservoirs, rice fields, salterns) (IUCNSL, 2004).

\section{Bellanwila-Attidiya Sanctuary}

Bellanwila-Attidiya Sanctuary (BAS) is listed in the directory of Asian wetlands by the IUCN in 1989 and designated as an Important Bird Area by Birdlife International (www.birdlife.org, accessed $7 / 8 / 2009$ ). It was declared a sanctuary under the fauna and flora protection ordinance by gazette extraordinary No. 620/9 of 25th July 1990 (Gunawardana, 1991). BAS is situated within the upper catchments of the Bolgoda river basin. The core study area is roughly $1-2 \mathrm{~km} \times 0.5 \mathrm{~km}$ (nearly $372 \mathrm{ha}$ ), at a mean elevation of $0.6 \mathrm{~m}$ above sea level. BAS area lies at the intersection of $6^{\circ} 48^{\prime}-52^{\prime}$ $\mathrm{N}$ and $79^{\circ} 52^{\prime}-56^{\prime} \mathrm{E}$ (IUCNSL \& CEA, 2006; Maduranga, 2005). This area is situated within the low country wet zone and has a tropical monsoonal climate (Gunatilleke \& Gunatilleke, 1990). Mean annual temperature is approximately $\sim 28{ }^{\circ} \mathrm{C}$ and average annual rain fall for the study area is about $2800 \mathrm{~mm}$ (CEA / Euroconsult, 1993).

The Bellanwila-attidiya sanctuary was surveyed by various conservationists and scientists from the early 1980's (CEA / Euroconsult, 1993; Dissanayaka \& Mahaulpaha 2006; Goonatilake, 1998; Goonatilake et al., 2001; Gunatilleke, 1992; Gunawardana, 1991; Henkanaththegedara et al., 2005; Maduranga, 2005; Nalinda, 1988; Nanayakkara, 1988). The BAS marsh consist of several habitat types which can be categorized as shallow freshwater ponds, canals, marshes, seasonally flooded grasslands, scrublands, and paddy fields. The survey was expanded to include a man-made reservoirs, home gardens, scrublands and grasslands immediately outside its boundary (Henkanaththegedara et al., 2005). The vegetation of BAS area is mainly composed of rooted emergents such as Rhyncospora sp., Eleocharis sp., and grasses such as Brachiaria sp., Bacopa sp. that grow extensively along the fringes of ponds 
(Maduranga, 2005). The water surfaces are covered with Salvinia molesta, Eichhornia crassipes and flowering ornamental species such as Nymphaea sp. and Nelumbo nucifera. The margins of marshy areas and the banks of the canal are covered with mixed vegetation of Annona glabra, Cerbera manghas, Syzygium sp., Melastoma sp. (Henkanaththegedara et al., 2005). Invasive alien species such as Lantana camara are also common.

\section{Materials and Methods}

Data were collected from random field observations during a number of visits from June 2005 to June 2006 (one year study). A summary of these data were previously posted on the Environment Sri Lanka Blog (Karunarathna, 2008). Visual encounter survey methods were used in preparing this faunalist. The fish faunal data were collected from the catches of fishermen using cast nets, hooks, ropes and gill nets. In addition, fish in shallow areas were sampled by using small trawl nets and hand nets. The avifaunal data were collected by using a standard binocular, and by calls and songs. Mammal fauna were documented through direct observations and indirect methods (eg. foot prints). Amphibian and reptile (Herpetofauna) data were assembled by collecting road kills and specimens killed by villagers and by searching under logs, stones and boulders. Several nocturnal field visits were also made in walking throughout the study area. Some small butterflies were captured using a butterfly net and closely observed using a clear glass bottle.

Vertebrates and invertebrate species were identified and classified by using published field guides (for freshwater fishes - Maduranga (2003), Pethiyagoda (1991), but later some species were confirmed by Silva et al. (2008; 2010), Pethiyagoda et al. (2008a; 2008c); Amphibians - Dutta \& ManamendraArachchi (1996), Manamendra-Arachchi \& Pethiyagoda (2005), Manamendra-Arachchi \& Pethiyagoda (2006); Reptiles - Das \& de Silva (2005), Deraniyagala (1953; 1955), de Silva (1990), De Silva (1980), Whitaker \& Captain (2004); Birds - Harrison (1999), Rasmussen \& Anderton (2005); Mammals - Phillips (1980); Butterflies - D'Abrera (1998), Woodhouse (1952), Kunte (2006). Threatened categories were assigned according to IUCNSL \& MENR (2007) and some floral species were identified by Ashton et al. (1997).

\section{Threats}

Considerable land area of BAS wetland has been lost due to:
(01) Habitat fragmentation

(02) Changes in water level that degraded native vegetation habitat and provided access for invasive native and non-native weeds and accelerated the succession decline of BAS habitat.

(03) Excess run-off of sediment, fertilizer, industrial waste, human sewage, animal waste, road salts, pesticides, heavy metals, leakage from landfills and dumps, toxic pollutants and nutrients that pollute wetlands and it exceeded the wetland's natural ability to absorb such pollutants and cause degradation. The extra nutrients are rapidly taken up by some types of aquatic plants such as Eichhornia crassipes. As the numbers of these plants increase, they become dominant over plants living on the sediment.

(04) Plant and animal pest invasion.

(05) Livestock grazing in surrounding catchments and in the BAS wetlands that damages vegetation, decreases soil stability and adds to pollution.

(06) Loss of natural character (i.e. the natural appearance of wetlands in the landscape) and changes in plant dominance have profound effects on the animals that depend upon aquatic environments as a source of food and refuge and as a nursery for their young.

(07) Hunting and carelessness human activity disturbs plant and animal life and may destroy parts of the physical wetland environment.

(08) Inappropriate use of surrounding land in a catchment (eg. poorly managed farming practices causing sedimentation and/or fertilizer run-off).

(09) Land filling and drainage of wetlands for urban or rural development.

Although legislation has greatly slowed wetland loss, the above sources of degradation continue.

\section{Results and Discussion}

The present study, the first to comprehensively document biodiversity within BAS, recorded 152 species of vertebrate fauna, 75 species of butterflies from BAS (Table - 1). Of the total number of species recorded, $16(7 \%)$ are endemic, while 5 $(\sim 2.2 \%)$ are nationally threatened (IUCNSL \& MENR, 2007). The vertebrates comprised 11 (7.2\%) species of amphibians, $27(17.8 \%)$ species of 
reptiles, $14(9.2 \%)$ species of mammals, $78(51.3 \%)$ species of birds, $22(14.5 \%)$ species of fishes. Birds were the most abundant faunal group in BellanwilaAttidita Sanctuary, according to the present survey; amphibian and mammals were the least abundant faunal groups. Among them $12(5.2 \%)$ are near threatened and $4(1.7 \%)$ species are data deficient.

Table 01: Faunal diversity of Bellanwila-Attidiya Sanctuary and its vicinity BAS

\begin{tabular}{|c|c|c|c|c|c|c|}
\hline Taxa & $\begin{array}{c}\text { No. of } \\
\text { Families }\end{array}$ & $\begin{array}{l}\text { No. of } \\
\text { Genera }\end{array}$ & $\begin{array}{c}\text { Endemic } \\
\text { Genera }\end{array}$ & $\begin{array}{l}\text { No. of } \\
\text { species }\end{array}$ & $\begin{array}{c}\text { Endemic } \\
\text { species }\end{array}$ & $\begin{array}{c}\text { Threatened } \\
\text { species }\end{array}$ \\
\hline Amphibians & 5 & 10 & 0 & 11 & 3 & 0 \\
\hline Birds & 38 & 68 & 0 & 78 & 4 & 0 \\
\hline Fishes & 11 & 12 & 0 & 22 & 2 & 1 \\
\hline Mammals & 9 & 11 & 0 & 14 & 0 & 1 \\
\hline Reptiles & 10 & 22 & 2 & 27 & 6 & 0 \\
\hline Butterflies & 5 & 55 & 0 & 75 & 1 & 3 \\
\hline Total & 78 & 178 & 2 & 227 & 16 & 5 \\
\hline
\end{tabular}

The amphibians consisted of 11 species (3 endemics) belonging to 5 families (Appendix - 1), including toads, narrow-mouthed frogs, aquatic frogs and tree frogs. These represented approximately $10.1 \%$ of the total amphibian species in the island. Among them, 5 species are very common, they are Duttaphrynus melanostictus, Euphlyctis cyanophlyctis, Euphlyctis hexadactylus, Hoplobatrachus crassus and Philautus popularis, while 3 species are very rare at BAS, they are Microhyla rubra, Hylarana gracilis and Polypedates cruciger. Most of these species could be observed after a short spell of rain at night. However, no nationally threatened species were recorded in the BAS. According to Goonatilake et al. (2001) 15 species of amphibians were recorded in BAS area, but we failed to record Duttaphrynus atukoralei, Hylarana aurantiaca, Sphaerotheca rolandae, Philautus leucorhinus and Philautus variabilis. The latter 2 species are currently known as extinct. Philautus popularis was the only shrub frog recorded in BAS. Amphibians play a vital role in the functioning of natural ecosystems. Because they consume a large biomass of insects they act as natural control agents of pests in both human settlements and agricultural landscapes.

The reptiles consisted of 27 species (6 endemics) belonging to 10 families (Appendix - 2), covering $13 \%$ of the island reptiles fauna. These included 11 species of tetrapod reptiles and 16 species of Serpentoid reptiles. Among the total species, 2 species are near threatened. Calotes calotes, Calotes versicolor, Gehyra mutilata, Hemidactylus parvimaculatus, Hemidactylus frenatus, Ptyas mucosa, Varanus bengalensis and Varanus salvator were the most common reptiles at BAS. Oligodon sublineatus, Sibynophis subpunctatus and Xenochrophis asperrimus are very rare in BAS. According to Nanayakkara (1988) 30 species of reptiles were recorded in BAS, but we failed to record Python molurus, Acrochordus granulatus, Lycodon striatus, Oligodon arnensis, Dendrelaphis bifrenalis, Cerberus rynchops, Hypnale hypnale, Lissemys punctata and Crocodylus porosus species. The snakes, both venomous and non-venomous, are widely killed in BAS due to fear and ignorance, as a precaution against snakebite. Also, several road kills were recorded during the study period, such as: Cylindrophis maculata, Coeloganthus helena, Oligodon sublineatus and Sibynophis subpunctatus. But no record of any sea snake species in the BAS area. The reptile family in which the largest number of species was recorded was Colubridae.

A total of 14 species of mammals, belonging to 9 families, were recorded in BAS (Appendix - 3), covering $13.9 \%$ of the island mammal fauna. These include the vulnerable Prionailurus viverrinus. No endemics were recorded. The mammals have diverse food habits, and could be categorized as granivorus, frugivorous, carnivorous and insectivorous. Pteropus giganteus, Herpestes brachyurus, Herpestes edwardsii, Bandicota bengalensis, Bandicota indica, Rattus rattus and Funambulus palmarum were the most common mammals, while Kerivoula picta and Hystrix indica were very rare in BAS. According to Goonatilake 
(1998), 27 species of mammals were recorded in BAS area, but we failed to the record Lutra lutra, Moschiola kathygre, Canis aureus, Prionailurus rubiginosus, Mus musculus, Golunda ellioti, Lepus nigricollis, Semnopithecus vetulus, Rousettus leschenaultia, Cynopterus sphinx and Hipposideros ater. The rats are often considered as pests because they feed or damage the food and cultivations. A Hystrix indica individual was captured from a canal bank in BAS. The Painted bat is one of the most significant records within this area.

A total of 22 species of fish, belonging to 11 families, were recorded in BAS (Appendix - 4), covering $18.2 \%$ of the island fish fauna. Few native species were recorded in study area; most were nonnative, such as the invasive alien species Pterygoplichthys multiradiatus. Out of these 22 species, 1 is vulnerable, 1 is near threatened, 1 is data deficient and 2 are endemic. The fish fauna is mainly based in the Thel Ela and Katu Ela area at BAS and others are around the Bellanwila temple. The most common fish species are Oreochromis mossambicus and Pterygoplichthys multiradiatus, while Lepidocephalichthys thermalis and Puntius chola are rare in BAS. These fish form an important component of the diet of aquatic birds such as Pelecanus philippensis and Phalacrocorax fuscicollis in BAS. According to Maduranga (2005) and Nalinda (1988), 33 fish species were recorded in BAS area, but we failed to the record Megalops cyprinoides, Amblypharyngodon melettinus, Esomus thermoicos, Rasboroides atukorali, Puntius vittatus, Mystus keletius, Clarias brachysoma, Aplocheilus dayi, Laubuca sp., Etroplus maculatus and Channa orientalis. Water pollution is major threat to the survival of fishes and habitat loss due to the reclamation of land and destruction of vegetation. It is a fact that the exotic species become dominant in a new habitat when the environmental conditions are conducive. Due to anthropogenic activities, the habitat quality for the resident species might become less favourable so that the exotic species might get a competitive advantage to become an invasive species. According to Vale'ry et al. (2008), a biological invasion consists of a species' acquiring a competitive advantage following the disappearance of natural obstacles to its proliferation, which allows it to spread rapidly and to conquer novel areas within recipient ecosystems in which it becomes a dominant population.

Birds appeared to be the dominant group of vertebrates at BAS, consisting of 78 species (4 endemics) belonging to 38 families (Appendix - 5).
BAS has is a paradise for birds, including many migratory species, and these represented approximately $15.8 \%$ of Sri Lankan avifauna. Among the total species, 9 winter migrants were recorded, while 1 species (Pelecanus philippensis) is globally threatened and 2 species are near threatened. But we fail to record some interesting birds such as, Pellorneum fuscocapillus, Plegadis falcinellus, Pomatorhinus melanurus and Caprimulgus asiaticus in this study. The mixture of vegetation types and aquatic habitats in BAS has made it an ideal ecotone for a variety of birds, where about half of the birds species recorded were those associated with wetland ecosystems, such as herons, egrets, cormorants, kingfishers and pelicans, all which feed on aquatic organisms. This area an important breeding habitat of native birds, and it is also a preferred feeding and resting habitat of several species. Most significant record was Chestnut-winged cuckoo in single time. Megalaima zeylanica, Halcyon smyrnensis, Centropus sinensis, Psittacula krameri, Mesophoyx intermedia, Ardeola grayii and Columba livia [domestic (but according to IUCN \& MENR, 2007 it is critically endangered)] were very common birds, while Spilornis cheela, Picus chlorolophus, Megalaima flavifrons, Anhinga melanogaster, Dupetor flavicollis, Ducula aenea, Haliaeetus leucogaster and Pelargopsis capensis were very rare at BAS. According to Gunawardana (1991) 153 species of birds were recorded in BAS, but we failed to record even half of them.

We recorded a rich array of butterflies in BAS, including 75 species, belonging to 5 families (Appendix - 6). The butterflies represented approximately $30.9 \%$ of the total species in the island; 1 species is endemic, 3 species are nationally threatened and 7 species are near threatened. The butterflies are a group of charismatic insects in Sri Lanka, which forms a major component of the island's biodiversity. Among them, Papilio domoleus, Graphium Agamemnon, Leptosia nina, Delias eucharis, Catopsilia pyranthe, Eurema hecabe, Danaus genutia, Junonia atlites, Telicota colon, Acraea violae, Ypthima ceylonica, Jamides celeno and Zizula hylax were the most common. Eurema blanda, Spalgis epeus, Curetis thetis, Zesius chrysomallus, Troides darsius, Tajuria cippus, Charaxes solon, Rathinda amor and Hypolycaena nilgirica were rare at BAS. According to Gunatilleke (1992) and Henkanaththegedara et al. (2005) 61 and 70 were recorded in BAS respectively, but we failed to record Chilades pandava, Lampides boeticus, Nacaduba sinhala, 
Elymnias singala, Mycalensis mineus, Vanessa cardui and Eurema brigitta species. The distribution of the butterflies in various habitat types needs further investigation and this study is just a beginning and paves the way for further studies. The highest diversity of butterflies was recorded from the open scrub jungles while the lowest close canopy habitats. The largest number of species was from the family Nymphalidae (28 sp.), followed by the families Lycaenidae (19 sp.), Papilionidae (11 sp.), Hesperiidae (11 sp.) and Pieridae (6 sp.).

In each taxon, we failed to record all species that had been recorded in previous studies. In some cases, this might be because the previous studies were more thorough or better sampled all types of habitats and seasons. However, it could also be that the continuing habitat deterioration and encroachment of settlement and human activities, persecution of snakes has actually extirpated some of the species that formerly occurred here. This is certainly the case with the 2 species of amphibians noted above as extinct, We believe that most of the species "missing" in this survey have, in fact, been locally extirpated from the Bellanwila-Attidiya Sanctuary. The habitat deterioration, extinction of at least 2 species (if confirmed by more extensive surveys) and local extirpation of many species, have been caused by poor protection, resulting in the "deplorable state of the Bellanwila-Attidiya Sanctuary, beset on all sides by unauthorized construction, garbage dumping and unsustainable livelihoods..." (Amaleeta, 2006).

\section{Acknowledgements}

The authors wish to thank Prof. Upali Amarasinghe for reviewing the document. Then the first author is grateful to Sarath Ekenayake, Naalin Perera, Mendis Wickramasinghe and Sampath Goonatilake for valuable support. Finally we thank Chamila Soysa, Toshan Peiris, Panduka Silva, Asanka Udayakumara, Anushka Kumarasinghe, Gayan Pradeep, Manori Athukorale, Praneeth Alwis, Harshani Maithripala, Kasun Ekanayake, Surangi Jayasekara, Marlon Perera, Sujan Maduranga, Ramyanath Sirimanna, Niranjan Karunarathna, Shanitha Wijesinghe, Thilina Degodagamage, Nadeesh Gamage, Kosalani Pradepika, Faraj Farook, Jaleel Ziyard, Tiran Abeywardena and Chandana Asela for their help and activities during the field visits in Bellanwila-Attidiya Sanctuary.

\section{Literature Cited}

Achard, F., H. D. Eva, H. Stibig, P. Mayaux, J. Gallego, T. Ricahards and J. Malingreau, 2002.
Determination of deforestation rates of the world's humid tropical forests. Science, 297: 999-1002.

Amaleeta, N. 2006. Bellanwila-Attidiya: in a state of daunting disgrace! In The Nation (Sri Lanka) posted 2006/08/27/. Available at www.nation.lk/2006/08/27/ eyefea2.htm. Colombo.

Ashton, M., C. V. S. Gunatileke, N. De Zoysa, M. D. Dassanayake, N. Gunatileke and S. Wijesundara, 1997. A field guide to the Common Trees and Shrubs of Sri Lanka. Wildlife Heritage Trust of Sri Lanka, Colombo: 432.

Bahir, M. M., 2009. Some Taxonomic inaccuracies in Conservation publications, Current Science, 96 (5): 632-633.

Bahir, M. M. and D. E. Gabadage, 2009a. Taxonomic and scientific inaccuracies in a consultancy report on biodiversity: a cautionary note. Journal of Threatened Taxa, 1 (6): 317-322.

Bahir, M. M. and D. E. Gabadage, 2009b. Taxonomic errors and inaccuracies in Sri Lanka's Red List, 2007: a cautionary note. Journal of Threatened Taxa, 1 (10): $525-529$.

Bambaradeniya, C. N. B., 2002. The status and implications of invasive alian species in Sri Lanka. Zoos’ Print Journal, 17 (11): 930-935.

Batuwita, S. and M. M. Bahir, 2005. Description of five new species of Cyrtodactylus from Sri Lanka. In: Yeo, D. C. J., P. K. L. Ng and R. Pethiyagoda (Eds.). Contributions to biodiversity exploration and research in Sri Lanka. The Raffles Bulletin of Zoology, Supplement No. 12: 351-380.

Bossuyt, F., M. Meegaskumbura, N. Beenaerts, D. J. Gower, R. Pethiyagoda, K. Roelants, A. Mannaert, M. Wilkinson, M. M. Bahir, K. Manamendra-arachchi, P. K. L. Ng, C. J. Schneider, O. V. Oommen and M. C. Milinkovitch, 2004. Local endemism within the Western Ghats - Sri Lanka Biodiversity Hotspot. Science, 306: 479-481.

Bossuyt, F., M. Meegaskumbura, N. Baenerts, D. J. Gower, R. Pethiyagoda, K. Roelants, A. Mannaert, M. Wilkinson, M. M. Bahir, K. Manamendra-Arachchi, P. K. L. Ng, C. J. Schneider, O. van Oomen \& M. C. Milinkovitch. (2005). Biodiversity in Sri Lanka and Western Ghats. Science, 308: 199.

Brook, B. W., N. S. Sodhi and P. K. L. Ng, 2003. Catastrophic extinctions follow deforestation in Singapore. Nature, 424: 420-423. 
CEA/Euroconsult, 1993. Wetland site report and conservation management plan, Bellanwila-Attidiya Marsh. Wetland Conservation Project: 83

Cincotta, R. P., J. Wisnewski and R. Engelman, 2000. Human populations in the biodiversity hotspots. Nature, 404: 990-992.

D' abrera, B., 1998. The Butterflies of Ceylon. Wildlife Heritage Trust, Colombo, Sri Lanka: 224.

Das, I. and de Silva, A., 2005. Photographic guide to the Snakes and other Rteptiles of Sri Lanka. New Holland Publishers: 144.

Daszak, P., A. A. Cunningham and A. D. Hyatt, 2000. Emerging infectious diseases of wildlife threats to biodiversity and human health. Science, 287: 443-449.

Deraniyagala, P. E. P., 1953. A Colored Atlas of some vertebrates from Ceylon, Tetrapod Reptilia, National Museums of Sri Lanka, Colombo. Vol. 02: 101.

Deraniyagala, P. E. P., 1955. A Colored Atlas of Some Vertebrates from Ceylon, Serpentoid Reptilia, The National Museums of Sri Lanka, Vol. 03: 200.

De Silva, P. H. D. H., 1980. Snakes Fauna of Sri Lanka, with special reference to skull, dentition and venom in snakes. The National Museums of Sri Lanka, Colombo: 472.

de Silva, A., 1990. Colour Guide to the snakes fauna of Sri Lanka. R and A Publishing Ltd, Avon, England: 130.

Dissanayaka, U. and D. Mahaulpaha, 2006. Diurnal avifaunal diversity, species richness and density along the Bolgoda canal in the Bellanwila-Attdiya sanctuary, western Sri Lanka. Eleventh International Forestry and Environment Symposium, Department of forestry and Environmental Science, University of Sri Jayewardenepura, Sri Lanka: 73.

Dutta, S. K. and K. N. Manamendra-Arachchi, 1996. The Amphibian Fauna of Sri Lanka. Wildlife Heritage Trust of Sri Lanka: 230.

Elton, C. S., 1958. The ecology of invasions by animals and plants. London, Methuen: 181.

Ferraz, G., G. J. Russell., P. C. Stouffer., R. O. Bierregaard, Jr., S. L. Pimm and T. E. Lovejoy, 2003. Rates of Species Loss from Amazonian Forest Fragments. Proceedings of the National Academy of Sciences of the United States of America, 100: 1406914073.
Goonatilake, W. L. D. P. T. S. D. A., 1998. A checklist of the some fauna in Bellanwila-Attidiya Sanctuary, Colombo, Sri Lanka: (Unpublished)

Goonatilake, W. L. D. P. T. S. D. A., L. J. K. R. Perera and D. E. Gabadage, 2001. Amphibians of BellanwilaAttidiya Sanctuary. Loris, 22 (5): 10-14.

Gunatilleke, I. A. U. N. and C. V. S. Gunatilleke, 1990. Dristribution of floristic richness and its conservation in Sri Lanka. Conservation Biology, 4 (1): 21-31.

Gunatilleke, A. K., 1992. A checklist of the Butterfly fauna of Attidiya. Parisara Sangrahaya: 4.

Gunawardana, J., 1991. Checklist of the Birds of the Bellanwila-Attidiya Sanctuary. Ceylon Bird Club, Colombo. Sri Lanka: 18.

Gunawardene, N. R., A. E. D. Daniels, I. A. U. N. Gonatilleke, C. V. F. Gonatilleke, P. V. Karunakaran, K. G. Nayak, S. Prasad, P. Puyravaud, B. R. Ramesh, K. A. Subramanian and G. Vasanthy, 2007. A Brief overview of the Western Ghats-Sri Lanka Biodiversity Hotspot. Current Science, 93: 1567-1572

Harrison, J., 1999. A Field Guide to the Birds of Sri Lanka. Oxford University Press, Oxford: 219.

Harvell, C. W., C. E. Mitchell, J. R. Ward, S. Altizer, A. P. Dobson, R. S. Ostfeld and M. D. Samuel, 2002. Climate warming and disease risks for terrestrial and marine biota. Science, 296: 2158-2162.

Hayes, T., K. Haston, M. Tsui, A. Hoang, C. Haeffele and A. Vonk, 2002. Feminization of male frogs in the wild. Nature, 419: 895-896.

Helgen, K. M. and C. P. Groves, 2005. Biodiversity in Sri Lanka and Western Ghats. Science, 308: 199.

Henkanaththegedara, S. M., B. J. Herath and D. J. Korala, 2005. Butterfly fauna of Bellanwila-Attidiya Sanctuary and its environs, Colombo district in Sri Lanka. Sri Lanka Naturalist, 7 (1\&2): 1-6.

Hewawasam, T., F. Von Blanckenburg, M. Schaller and P. Kubik, 2003. Increase of human over natural erosion rates in tropical highlands constrained by cosmogenic nuclides. Geology, 31: 597-600.

IUCNSL, 2004. Wetland conservation in Sri Lanka. Proceedings of National Symposium of the Wetland conservation and management, IUCN, Sri Lanka: 92. 
IUCNSL and CEA, 2006. National Wetland Directory of Sri Lanka. IUCN Sri Lanka, Colombo: 342.

IUCNSL and MENR, 2007. The 2007 Red List of threatened Fauna and Flora of Sri Lanka. IUCN Sri Lanka, Colombo: 148.

Jenkins, M., 2003. Prospects for Biodiversity. Science, 302: 1175-1177.

Karunarathna, D. 2008. Diurnal avifaunal diversity, species richness and density along the Bolgoda canal in the Bellanwila-Attidiya sanctuary, western Sri Lanka. In Environment Sri Lanka Blog (http:/environmentlanka.com/blog/2008, posted March 10, 2008. Department of Forestry and Environment Science, University of Sri Jayewardenepura, Colombo.

Kunte, K., 2006. India - A lifescape, Butterflies of Peninsular India. University Press (India) Privet Limited: 254.

Vale'ry, L., H. Fritz, J-C. Lefeuvre and D. Simberloff, 2008. In search of a real definition of the biological invasion phenomenon itself. Biological Invasions: DOI 10.1007/s10530-007-9209-7.

Maduranga, H. G. S., 2003. Endemic Freshwater fish of Sri Lanka (text in Sinhala). National Zoological gardens of Sri Lanka: 122.

Maduranga, H. G. S. 2005. Ichthyofauna of Bellanwila-Attidiya Sanctuary and its environs in Colombo, Sri Lanka. Tigerpaper, 32 (1): 26-32.

Manamendra-Arachchi, K. and R. Pethiyagoda, 2005. The Sri Lankan shrub-frogs of the genus Philautus Gistel, 1848 (Ranidae: Rhacophorinae), with description of 27 new species. In: Yeo, D. C. J., P. K. L. Ng and R. Pethiyagoda (Eds.). Contributions to biodiversity exploration and research in Sri Lanka. The Raffles Bulletin of Zoology, Supplement No. 12: 163303.

Manamendra-Arachchi, K. and R. Pethiyagoda, 2006. Amphibians of Sri Lanka (text in sinhala). Wildlife Heritage Trust of Sri Lanka: 440.

MacNeely, J. A., 1992. The sinking ark: pollution and the worldwide loss of biodiversity. Biodiversity \& Conservation, 1: 2-18.

Meegaskumbura, M., F. Bossuyt, R. Pethiyagoda, K. Manamendra-Arachchi, M. Bahir, M. Milinkovitch and C. Schneider, 2002. Sri Lanka: an amphibian hotspot. Science, 298: 379.
Meegaskumbura, M., K. Manamendra-Arachchi, C. J. Schneider and R. Pethiyagoda, 2007. New species amongst extinct shrub frogs (Amphibia; Rhacophoridae; Philautus). Zootaxa, 1397: 1-15.

Mittermeier, R. A., P. R. Gil, M. Hoffman, J. Pilgrim, T. Brooks, C. G. Mittermeier, J. Lamoreux and G. A. B. da Fonseca, 2004. Hotspots revisited: Earth's biologically richest and most threatened terrestrial ecoregions. CEMEX, Mexico City and Conservation International, Washington, D. C.: 164.

Myers, N., R.A. Mittermeier, C.G. Mittermeier, G.A.B. Fonseca, and J. Kent, 2000. Biodiversiy hotspots for conservation priorities. Nature, 403: 853858.

Nalinda, M-A. K., 1988. Checklist of the fishes (Pisces) of the Bellanwila-Attidiya Marshes. Young Zoologists' Association of Sri Lanka. Occasional paper $3: 4$.

Nanayakkara, G. L. A., 1988. Checklist of the Reptiles inhabiting the Bellanwila-Attidiya Marshes. Young Zoologists' Association of Sri Lanka. Occasional paper 4: 6 .

Pethiyagoda, R., 1991. Fresh water fishes of Sri Lanka. Wildlife Heritage Trust, Colombo, Sri Lanka: 362.

Pethiyagoda, R., 1994. Threats to the indigenous freshwater fishes of Sri Lanka and remarks on their conservation. Hydrobiologia, 285: 189-201.

Pethiyagoda, R., 2005. Exploring Sri Lanka's biodiversity. In: Yeo, D. C. J., P. K. L. Ng and R. Pethiyagoda (Eds.). Contributions to biodiversity exploration and research in Sri Lanka. The Raffles Bulletin of Zoology, Supplement No. 12: 1-4.

Pethiyagoda, R., 2007a. Pearls, Spices and Green Gold, an illustrated history of Biodiversity Exploration of Sri Lanka. Wildlife Heritage Trust of Sri Lanka, Colombo: 241.

Pethiyagoda, R., 2007b. The 'New species syndrome' in Sri Lankan herpetology: a cautionary note. Zeylanica, 7 (1): 1-7.

Pethiyagoda, R., A. Silva and K. Maduwage, 2008a. Mystus ankutta, a new catfish from Sri Lanka (Teleostei: Bagridae). Ichthyological Exploration of Freshwaters, 19 (3): 233-242.

Pethiyagoda, R., A. Silva, K. Maduwage and L. Kariyawasam, 2008b. The Sri Lankan spiny eel, 
Macroganathus pentophthalmos (Teleostei: Mastacembelidae) and its enigmatic decline. Zootaxa, 1931: 37-48.

Pethiyagoda, R., A. Silva, K. Maduwage and M. Meegaskumbura, 2008c. Puntius kelumi, a new species of cyprinid fish from Sri Lanka (Teleostei: Cyprinidae). Ichthyological Exploration of Freshwaters, 19 (3): 201-214.

Phillips, W. W. A., 1980. Manual of the mammals of Sri Lanka. Wildlife and Nature Protection Society of Sri Lanka (Part - I / II / III): 116, 117-267, 268-388.

Pounds, A. J., M. R. Bastamante, L. A. Coloma, J. A. Consuegra, M. P. L. Fogden, P. N. Foster, E. La Marca, K. L. Masters, A. Merno-Viteri, R. Puschendorf, S. R. Ron, G. A. Sanchez-Azofeifa, C. J. Still and B. E. Young, 2006. Widespread amphibian extinctions from epidemic disease driven by global warming. Nature, 439: 161-167.

Rasmussen, P. C. and J. C. Anderton, 2005. Birds of South Asia: The Ripley Guide. Vols. 1 and 2. Smithsonian Institution and Lynx Edicions, Washington, D.C. and Barcelona: 378, 683.

Roelants, K., J. Jiang and F. Bossuyt, 2004. Endemic Ranid (Amphibia: Anura) genera in southern mountain ranges of the Indian subcontinent represent ancient frog lineages: evidence from molecular data. Molecular Phylogenetics and Evolution. 31: 730-740.

Rosa, I. D., F. Simonselli, A. Fagotti and R. Pascoline, 2007. The proximate cause of frog decline?. Nature, 447: E4-E5.
Silva, A., K. Maduwage and R. Pethiyagoda, 2010. A review of the genus Rasbora in Sri Lanka, wih descrition of two new species (Teleostei: Cyprinidae). Ichthyological Exploration of Freshwaters, 21 (1): 27 50 .

Silva, A., K. Maduwage and R. Pethiyagoda, 2008. Puntius kamalika, a new species of barb from Sri Lanka (Teleostei: Cyprinidae). Zootaxa, 1824: 55-64.

Somasekaran, T., 1998. The National Atlas of Sri Lanka: Surveys Department Sri Lanka: 142.

Stuart, S., J. S. Chanson, N. A. Cox, B. E. Young, A. S. L. Rodrigues, D. L. Fischman and R. W. Waller, 2004. Status and trends of amphibian declines and extinctions worldwide. Science, 306: 1783-1786.

Swinbanks, D., 1997. Forest fires cause pollution crisis in Asia. Nature, 389: 321.

Whitaker, R. and A. Captain, 2004. Snakes of India, The field guide, Dracco Publication Limited. India: 481 .

Wittemyer, G., P. Elsen, W. T. Bean, A. C. O. Burton, J. S. Brashares, 2008. Accelerated human population growth at protected area edges. Science, 321: 123-126.

Woodhouse, L. G. O., 1950. The Butterfly fauna of Ceylon. Ceylon Government Press, Colombo: 284.

Appendix 01: List of the Amphibian species recoded from Bellanwila-Attidiya sanctuary (BAS). (Abbreviation: E Endemic species).

\begin{tabular}{|c|c|c|}
\hline & Species Name & Common Name \\
\hline \multicolumn{3}{|c|}{ Family - Bufonidae } \\
\hline 1 & Duttaphrynus melanostictus & Common house toad \\
\hline \multicolumn{3}{|c|}{ Family - Dicroglossidae } \\
\hline 2 & Euphlyctis cyanophlyctis & Skipper frog \\
\hline 3 & Euphlyctis hexadactylus & Sixtoe green frog \\
\hline 4 & Fejervarya limnocharis & Common paddy field frog \\
\hline 5 & Hoplobatrachus crassus & Jerdon's bull frog \\
\hline \multicolumn{3}{|c|}{ Family - Microhylidae } \\
\hline 6 & Kaloula taprobanica & Common bull frog \\
\hline 7 & Microhyla rubra & Red narrow mouth frog \\
\hline 8 & Ramanella variegata & White-bellied pugsnout frog \\
\hline
\end{tabular}


Family - Ranidae

9 Hylarana gracilis $\quad$ Sri Lanka wood frog ${ }^{\mathbf{E}}$

Family - Rhacophoridae

10 Philautus popularis Common shrub frog ${ }^{\mathbf{E}}$

11 Polypedates cruciger Common hour-glass tree frog ${ }^{\mathbf{E}}$

Appendix 02: List of the Reptile species recoded from Bellanwila-Attidiya sanctuary (BAS). (Abbreviations: NT Near Threatened Species and E - Endemic species).

\begin{tabular}{|c|c|}
\hline Species Name & Common name \\
\hline \multicolumn{2}{|l|}{ Family - Bataguridae } \\
\hline 1 Melanochelys trijuga & Parker's black turtle ${ }^{\mathrm{NT}}$ \\
\hline \multicolumn{2}{|l|}{ Family - Agamidae } \\
\hline 2 Calotes calotes & Green garden lizard \\
\hline 3 Calotes versicolor & Common garden lizard \\
\hline \multicolumn{2}{|l|}{ Family - Gekkonidae } \\
\hline 4 Gehyra mutilata & Four-claw gecko \\
\hline 5 Hemidactylus parvimaculatus & Spotted housegecko \\
\hline 6 Hemidactylus frenatus & Common house-gecko \\
\hline \multicolumn{2}{|l|}{ Family - Scincidae } \\
\hline 7 Lankascincus fallax & Common lankaskink ${ }^{\mathrm{E}}$ \\
\hline 8 Lygosoma punctatus & Dotted skink \\
\hline 9 Eutropis carinata & Common skink \\
\hline \multicolumn{2}{|l|}{ Family - Varanidae } \\
\hline 10 Varanus bengalensis & Land monitor \\
\hline 11 Varanus salvator & Water monitor \\
\hline \multicolumn{2}{|l|}{ Family - Cylindrophidae } \\
\hline 12 Cylindrophis maculata & Sri Lanka Pipe snake ${ }^{\text {E/NT }}$ \\
\hline \multicolumn{2}{|l|}{ Family - Colubridae } \\
\hline 13 Ahaetulla nasuta & Green vine snake \\
\hline 14 Amphiesma stolata & Buff striped keelback \\
\hline 15 Atretium schistosum & The Olive keelback watersnake \\
\hline 16 Coeloganthus helena & Trinket snake \\
\hline 17 Dendrelaphis schokari & Common bronze back \\
\hline 18 Lycodon aulicus & Wolf snake, house snake \\
\hline 19 Lycodon osmanhilli & Flowery wolf snake ${ }^{\mathbf{E}}$ \\
\hline 20 Oligodon sublineatus & Dumerul's kuki snake ${ }^{\mathbf{E}}$ \\
\hline 21 Ptyas mucosa & Rat snake \\
\hline 22 Sibynophis subpunctatus & Jerdon's polyodent \\
\hline 23 Xenochrophis asperrimus & The checkered keelback ${ }^{\mathbf{E}}$ \\
\hline 24 Xenochrophis cf. piscator & Checkered Keelback $^{\mathbf{E}}$ \\
\hline \multicolumn{2}{|l|}{ Family - Elapidae } \\
\hline 25 Naja naja & Indian cobra \\
\hline \multicolumn{2}{|l|}{ Family - Typhlopidae } \\
\hline 26 Ramphotyphlops cf. braminus & Common blind snake \\
\hline \multicolumn{2}{|l|}{ Family - Viperidae } \\
\hline 27 Daboia russelii & Russell's viper \\
\hline
\end{tabular}


Appendix 03: List of the Mammal species recoded from Bellanwila-Attidiya sanctuary (BAS). (Abbreviation: VU Vulnerable Species).

\begin{tabular}{|c|c|}
\hline Species Name & Common Name \\
\hline \multicolumn{2}{|l|}{ Family - Pteropodidae } \\
\hline 1 Pteropus giganteus & Flying fox \\
\hline \multicolumn{2}{|l|}{ Family - Vespertillionidae } \\
\hline 2 Kerivoula picta & Painted bat \\
\hline \multicolumn{2}{|l|}{ Family - Felidae } \\
\hline 3 Prionailurus viverrinus & Fishing cat ${ }^{\mathrm{VU}}$ \\
\hline \multicolumn{2}{|l|}{ Family - Herpestidae } \\
\hline 4 Herpestes brachyurus & Brown mongoose \\
\hline 5 Herpestes edwardsii & Grey mongoose \\
\hline \multicolumn{2}{|l|}{ Family - Viverridae } \\
\hline 6 Paradoxurus hermaphoditus & Palm cat \\
\hline 7 Viverricula indica & Ring-tailed civet \\
\hline \multicolumn{2}{|l|}{ Family - Hystricidae } \\
\hline 8 Hystrix indica & Porcupine \\
\hline \multicolumn{2}{|l|}{ Family - Muridae } \\
\hline 9 Bandicota bengalensis & Mole rat \\
\hline 10 Bandicota indica & Malabar bandicoot \\
\hline 11 Rattus norvegicus & Brown rat \\
\hline 12 Rattus rattus & Common rat \\
\hline \multicolumn{2}{|l|}{ Family - Sciuridae } \\
\hline 13 Funambulus palmarum & Palm squirrel \\
\hline \multicolumn{2}{|l|}{ Family - Soricidae } \\
\hline 14 Suncus murinus & Common musk shrew \\
\hline
\end{tabular}

Appendix 04: List of the Fish species recoded from Bellanwila-attidiya sanctuary (BAS). (Abbreviations: VU Vulnerable Species, DD - Data Deficient species, NT - Near Threatened Species and E - Endemic species).

\begin{tabular}{|c|c|}
\hline Species Name & Common Name \\
\hline \multicolumn{2}{|l|}{ Family - Cyprinidae } \\
\hline 1 Puntius kamalika & Kaamalika's barb ${ }^{\mathbf{E}}$ \\
\hline 2 Puntius bimaculatus & Redside barb \\
\hline 3 Puntius chola & Swamp barb \\
\hline 4 Puntius dorsalis & Long snouted barb \\
\hline 5 Puntius singhala & Filamented Barb ${ }^{\mathbf{E}}$ \\
\hline 6 Puntius sarana & Olive barb \\
\hline 7 Rasbora dandia & Striped rasbora \\
\hline \multicolumn{2}{|l|}{ Family - Cobitidae } \\
\hline 8 Lepidocephalichthys thermalis & Common spiny loach \\
\hline \multicolumn{2}{|l|}{ Family - Bagridae } \\
\hline 9 Mystus cavasius & Gangetic mystus ${ }^{\text {DD }}$ \\
\hline 10 Mystus gulio & Long-whiskered catfish \\
\hline 11 Mystus vittatus & Striped dwarf catfish \\
\hline
\end{tabular}




\begin{tabular}{|c|c|}
\hline \multicolumn{2}{|l|}{ Family - Heteropneustidae } \\
\hline 12 Heteropneustes fossilis & Stinging catfish \\
\hline \multicolumn{2}{|l|}{ Family - Anguillidae } \\
\hline 13 Anguilla bicolor & Level finned eel $^{\mathrm{NT}}$ \\
\hline 14 Anguilla nebulosa & Long finned eel ${ }^{\mathrm{VU}}$ \\
\hline \multicolumn{2}{|l|}{ Family - Aplocheilidae } \\
\hline 15 Aplocheilus parvus & Dwarf panchax \\
\hline \multicolumn{2}{|l|}{ Family - Gobiidae } \\
\hline 16 Awaous melanocephalus & Scribbled goby \\
\hline \multicolumn{2}{|l|}{ Family - Cichlidae } \\
\hline 17 Oreochromis mossambicus & Tilapia \\
\hline 18 Oreochromis niloticus & Nile tilapia \\
\hline \multicolumn{2}{|l|}{ Family - Loricarridae } \\
\hline 19 Pterygoplichthys multiradiatus & Tank cleaner \\
\hline \multicolumn{2}{|l|}{ Family - Poecilidae } \\
\hline 20 Poecilia reticulata & Guppy \\
\hline \multicolumn{2}{|l|}{ Family - Channidae } \\
\hline 21 Channa punctata & Spotted snakehead \\
\hline 22 Channa striata & Murrel \\
\hline
\end{tabular}

Appendix 05: List of the Bird species recoded from Bellanwila-attidiya sanctuary (BAS). (Abbreviations: M - Migrant Species, NT - Near Threatened Species, DD - Data Deficient species and E - Endemic species).

Species Name Common name

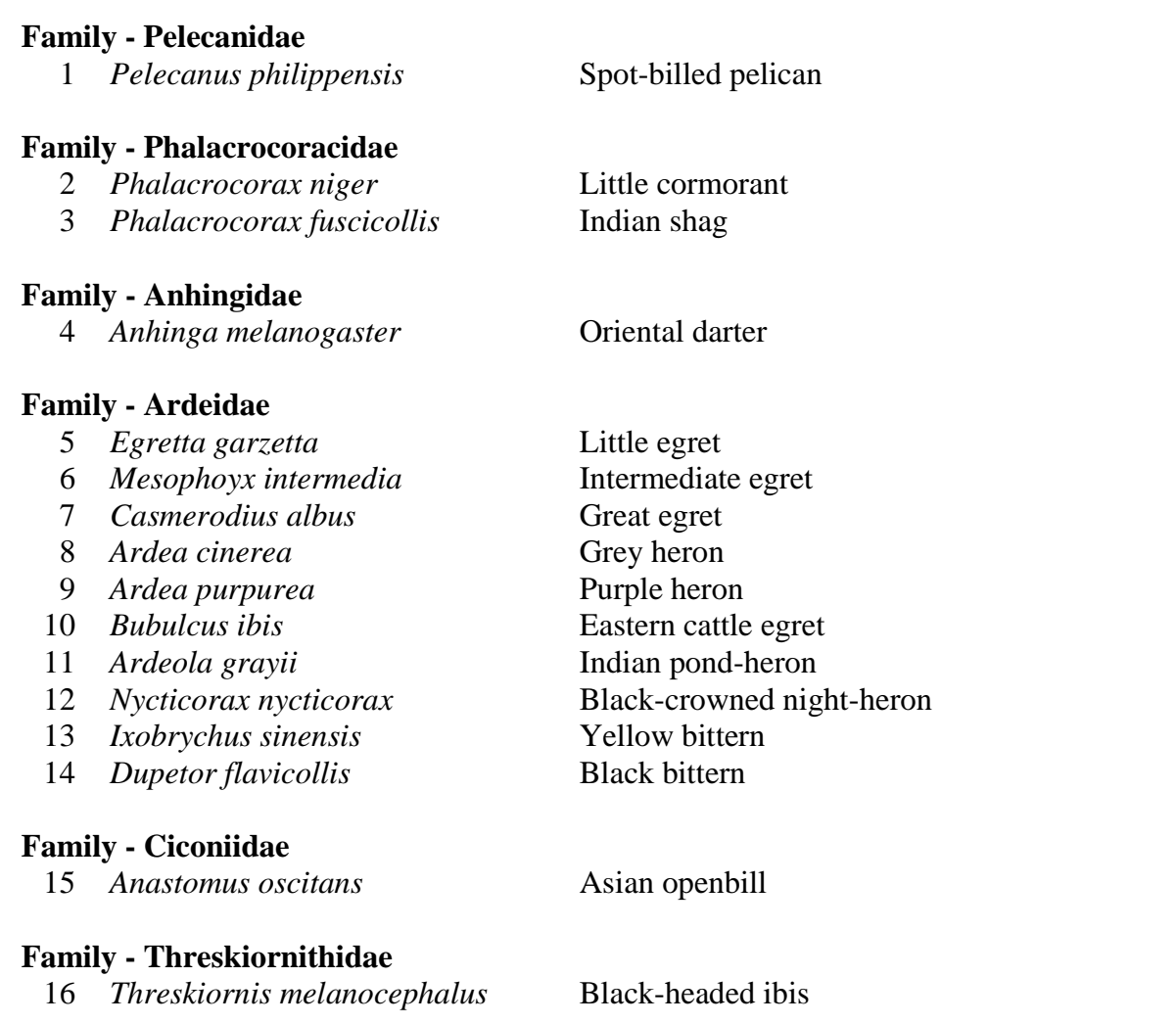


Family - Anatidae

17 Dendrocygna javanica

18 Anas querquedula

19 Nettapus coromandelianus

Family - Accipitridae

20 Haliastur indus

21 Haliaeetus leucogaster

22 Spilornis cheela

23 Accipiter badius

Family - Rallidae

24 Amaurornis phoenicurus

25 Porphyrio porphyrio

Family - Jacanidae

26 Hydrophasianus chirurgus

Family - Charadriidae

27 Himantopus himantopus

28 Vanellus indicus

Family - Scolopacidae

29 Actitis hypoleucos

30 Tringa stagnatilis

Family - Columbidae

31 Columba livia

32 Streptopelia chinensis

33 Ducula aenea

Family - Psittacidae

34 Loriculus beryllinus

35 Psittacula eupatria

36 Psittacula krameri

\section{Family - Cuculidae}

37 Centropus sinensis

38 Clamator jacobinus

39 Clamator coromandus

40 Eudynamys scolopaceus

41 Cuculus micropterus

Family - Strigidae

42 Otus bakkamoena

\section{Family - Apodidae}

43 Apus affinis

Family - Hirundinidae

44 Hirundo daurica

Family - Alcedinidae

45 Alcedo atthis

46 Pelargopsis capensis

47 Halcyon smyrnensis

Family - Cerylidae

48 Ceryle rudis
Lesser whistling-duck

Garganey ${ }^{\mathbf{M}}$

Cotton pygmy goose

Brahminy kite

White-bellied sea-eagle

Crested serpent-eagle

Shikra

White-breasted waterhen

Purple swamphen

Pheasant-tailed Jacana

Black-winged Stilt

Red-wattled lapwing

Common Sandpiper ${ }^{\mathbf{M}}$

Marsh sandpiper ${ }^{\mathbf{M}}$

Rock pigeon

Spotted dove

Green Imperial-pigeon

Ceylon hanging-parrot ${ }^{\mathbf{E}}$

Alexandrine parakeet

Rose-ringed parakeet

Greater coucal

Pied cuckoo

Chestnut-winged cuckoo ${ }^{\mathbf{M}}$

Asian Koel

Indian Cuckoo

Collared scops-owl

House swift

Red-rumped swallow $^{\text {E / NT }}$

Common kingfisher

Stork-billed kingfisher

White-throated kingfisher

Pied kingfisher 
Family - Meropidae

49 Merops philippinus

Family - Capitonidae

50 Megalaima zeylanica

51 Megalaima flavifrons

52 Megalaima rubricapillus

Family - Picidae

53 Picus chlorolophus

54 Dinopium benghalense

Family - Pittidae

55 Pitta brachyura

Family - Motacillidae

56 Dendronanthus indicus

57 Motacilla cinerea

Family - Pycnonotidae

58 Pycnonotus cafer

59 Pycnonotus luteolus

Family - Laniidae

60 Lanius cristatus

Family - Muscicapidae

61 Copsychus saularis

Family - Timaliidae

62 Turdoides affinis

\section{Family - Cisticolidae}

63 Cisticola juncidis

64 Prinia inornata

65 Orthotomus sutorius

Family - Dicaeidae

66 Dicaeum erythrorhynchos

Family - Nectariniidae

67 Cinnyris asiaticus

68 Cinnyris lotenius

Family - Estrildidae

69 Lonchura striata

Family - Passeridae

70 Lonchura striata

71 Lonchura punctulata

72 Passer domesticus

Family - Sturnidae

73 Acridotheres tristis

Family - Oriolidae

74 Terpsiphone paradisi

75 Oriolus xanthornus
Blue-tailed Bee-eater ${ }^{\text {M / DD }}$

Brown-headed barbet

Yellow-fronted barbet ${ }^{\mathbf{E}}$

Crimson-fronted barbet ${ }^{\mathrm{E}}$

Lesser yellownape ${ }^{\text {NT }}$

Black-rumped flameback

Indian pitta $^{\mathbf{M}}$

Forest wagtail $^{\mathbf{M}}$

Grey wagtail $^{\mathbf{M}}$

Red-vented bulbul

White-browed bulbul

Brown shrike ${ }^{\mathbf{M}}$

Oriental magpie-robins

Yellow-billed babbler

Zitting cisticola

Plain prinia

Common tailorbird

Pale-billed flowerpecker

Purple sunbird

Loten's sunbird

White-rumped munia

White-rumped munia Scaly-breasted munia House sparrow

Common myna

Asian Paradise-flycathcher Black-hooded oriole 
Family - Dicruridae

76 Dicrurus caerulescens

Family - Corvidae

77 Corvus splendens

78 Corvus macrorhynchos
White-bellied drongo

Housecrow

Jungle crow

Appendix 06: List of the Butterfly species recoded from Bellanwila-attidiya sanctuary (BAS). (Abbreviations: EN Endangered species, VU - Vulnerable Species, NT - Near Threatened Species, DD - Data Deficient specie and E Endemic species).

\section{Species Name Common Name}

\section{Family - Papilionidae \\ 1 Troides darsius \\ 2 Pachliopta hector \\ 3 Pachliopta aristolochiae \\ 4 Papilio crino \\ 5 Papilio domoleus \\ 6 Papilio polytes \\ 7 Papilio polymnestor \\ 8 Chilasa clytia \\ 9 Graphium sarpedon \\ 10 Graphium doson \\ 11 Graphium agamemnon}

\section{Family - Pieridae \\ 12 Leptosia nina \\ 13 Delias eucharis \\ 14 Appias albina \\ 15 Appias paulina \\ 16 Catopsilia pyranthe \\ 17 Catopsilia pomona}

\section{Family - Nymphalidae \\ 18 Eurema hecabe \\ 19 Eurema blanda \\ 20 Eurema andersoni \\ 21 Ideopsis similis \\ 22 Tirumala limniace \\ 23 Parantica aglea \\ 24 Danaus chrysippus \\ 25 Danaus genutia \\ 26 Euploea core \\ 27 Euploea phaenareta \\ 28 Euploea klugii \\ 29 Cupha erymanthis \\ 30 Junonia atlites \\ 31 Junonia iphita \\ 32 Junonia almana \\ 33 Hypolimnas bolina \\ 34 Hypolimnas misippus \\ 35 Neptis hylas \\ 36 Neptis jumbah \\ 37 Euthalia aconthea \\ 38 Charaxes solon \\ 39 Acraea violae \\ 40 Melanitis leda \\ 41 Orsotriaena medus}

\author{
Ceylon birdwing ${ }^{\text {E / NT }}$ \\ Crimson rose \\ Common rose \\ Banded peacock \\ Lime butterfly \\ Common mormon \\ Blue mormon \\ Mime $^{\text {NT }}$ \\ Blue bottle \\ Common jay \\ Tailed jay
}

Psyche

Jezebel

Common albatross

Lesser albatross

Mottled emigrant

Lemon emigrant

Common grass yellow

Three-spot grass yellow

One-spot grass yellow EN

Blue glassy tiger ${ }^{\text {NT }}$

Blue tiger

Glassy tiger

Plain tiger

Common tiger

Common crow

King crow ${ }^{\text {NT }}$

Brown king crow ${ }^{\text {NT }}$

Rustic NT

Grey pansy

Chocolate soldier

Peacock pansy

Great eggfly

Danaid Eggfly

Common sailor

Chestnut-streaked sailor

Baron

Black rajah $^{\text {NT }}$

Tawny costor

Common evening brown

Nigger 
42 Mycalesis perseus

43 Nissanga patnia

44 Ypthima ceylonica

45 Elymnias hypermnestra

Family - Lycaenidae

46 Spalgis epeus

47 Curetis thetis

48 Arhopala amantes

49 Zesius chrysomallus

50 Loxura atymnus

51 Rathinda amor

52 Tajuria cippus

53 Hypolycaena nilgirica

54 Jamides bochus

55 Jamides celeno

56 Catochrysops strabo

57 Castalius rosimon

58 Zizeeria karsandra

59 Zizina otis

60 Zizula hylax

61 Talicada nyseus

62 Euchrysops cnejus

63 Chilades lajus

64 Abisara echerius

Family - Hesperiidae

65 Ampittia dioscorides

66 Iambrix salsala

67 Panara bada

68 Pelopidas agna

69 Potanthus confuscius

70 Potanthus pseudomaesa

71 Spalia galba

72 Suastus gremius

73 Taractrocera maevius

74 Telicota ancilla

75 Telicota colon
Common bushbrown

Gladeye bushbrown

White four-ring

Common palmfly

Apefly

Indian sunbeam

Large oakblue

Redspot

Yamfly

Monkey-puzzle

Peacock royal

Nilgiri tit ${ }^{\text {Vu }}$

Dark cerulean

Common cerulean

Forger-me-not

Common pierrot

Dark grass blue

Lesser grass blue

Tiny grass blue

Red pierrot

Gram blue

Lime blue

Plum judy

Hedge hopper

Ceylon palm bob

Smallest swift

Little branded swift

Tropic dart

Common dart

Common red eye

Ceylon ace

Common grass dart

Dark palmdart ${ }^{\text {VU }}$

Pale palmdart 


\section{PLATE 02}

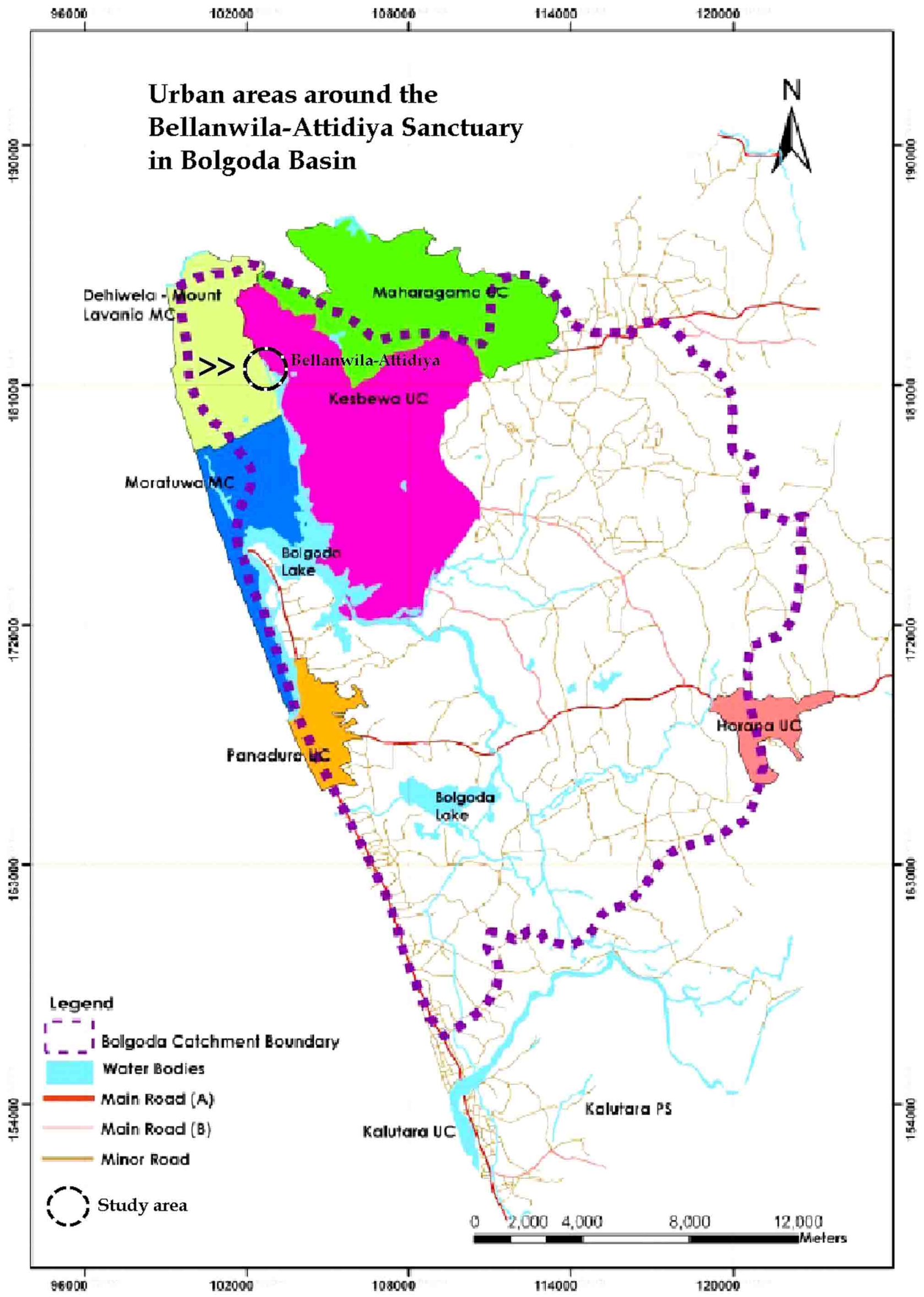

Fig. 01: Map of study area; Bellanwila-Atthidiya Sanctuary 


\section{PLATE 03}

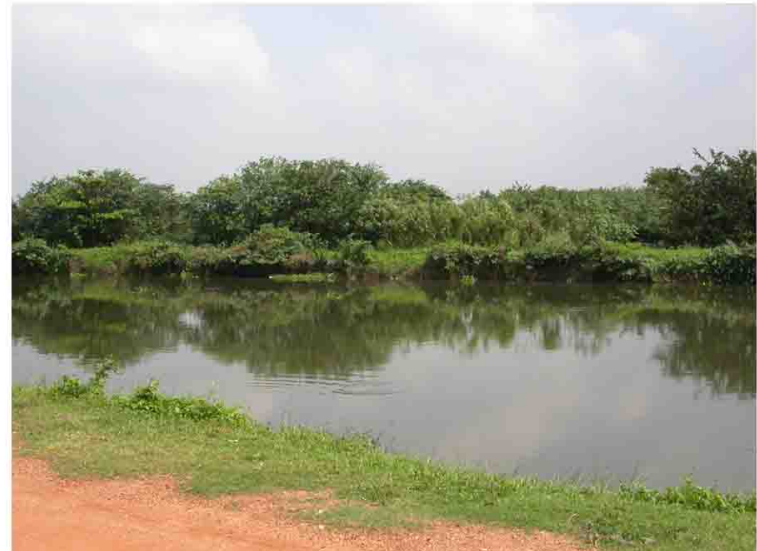

Fig. 02: Natural wetland habitat

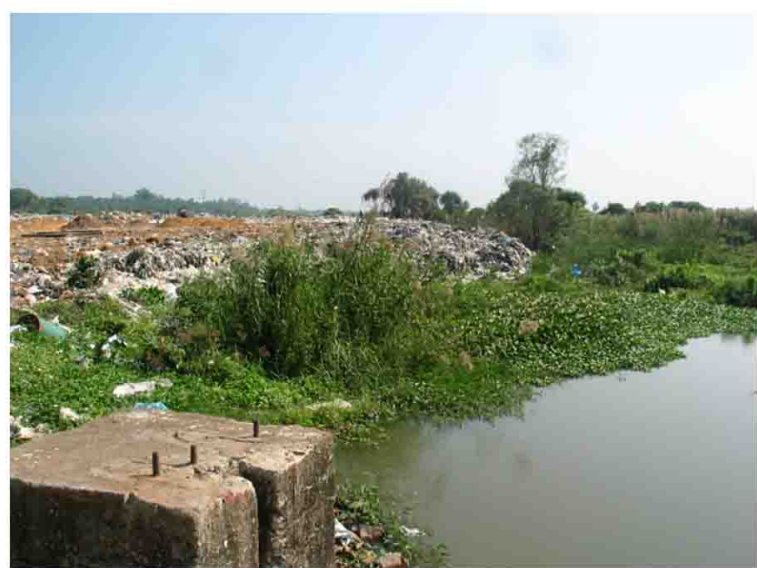

Fig. 04: Unplanned garbage dumping area

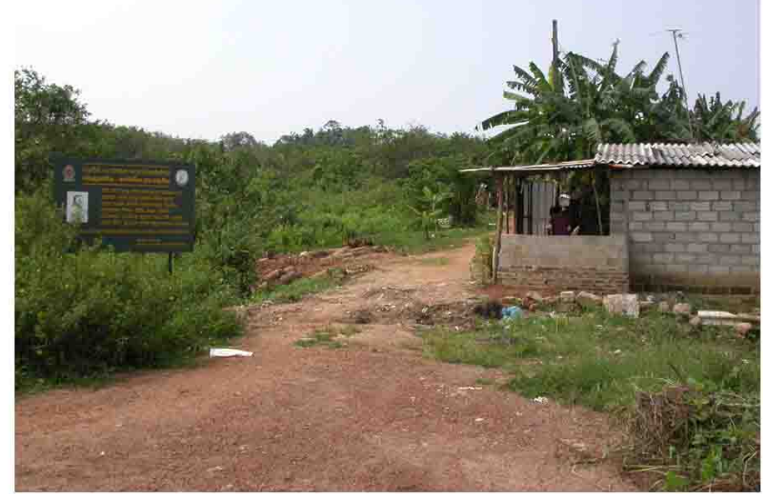

Fig. 06: Human encroachments

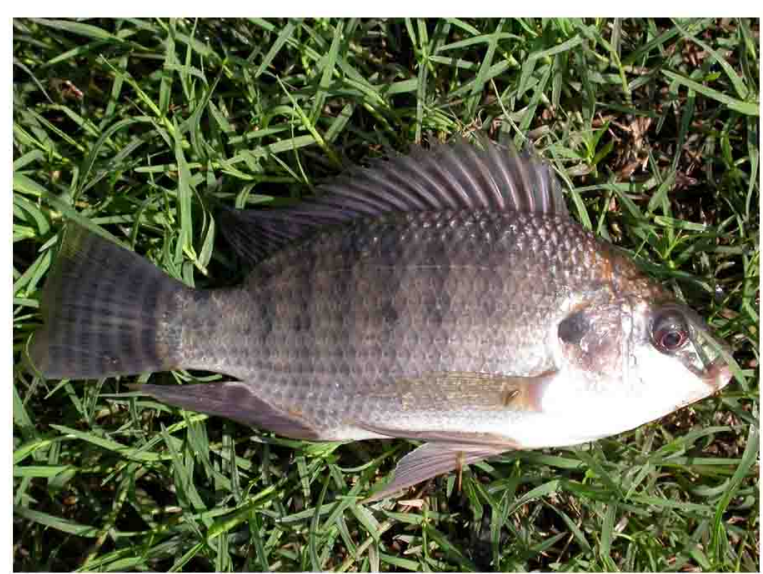

Fig. 08: Nile tilapia (Oreochromis niloticus)

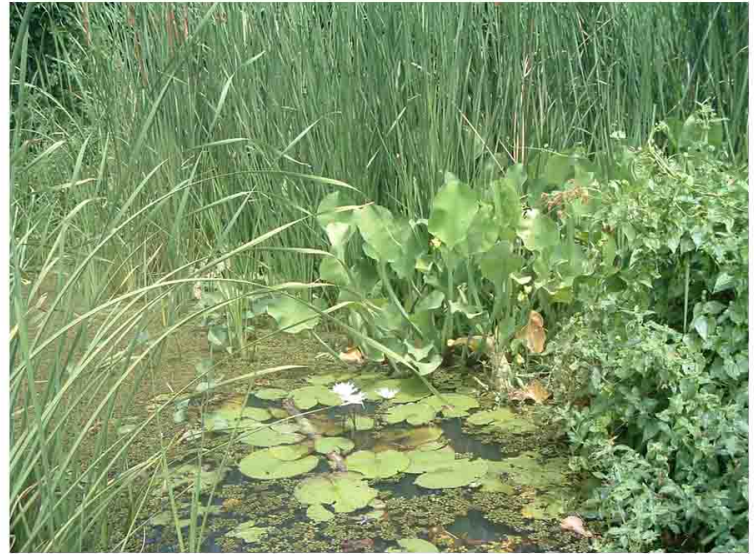

Fig. 03: Naïve and non native aquatic flora

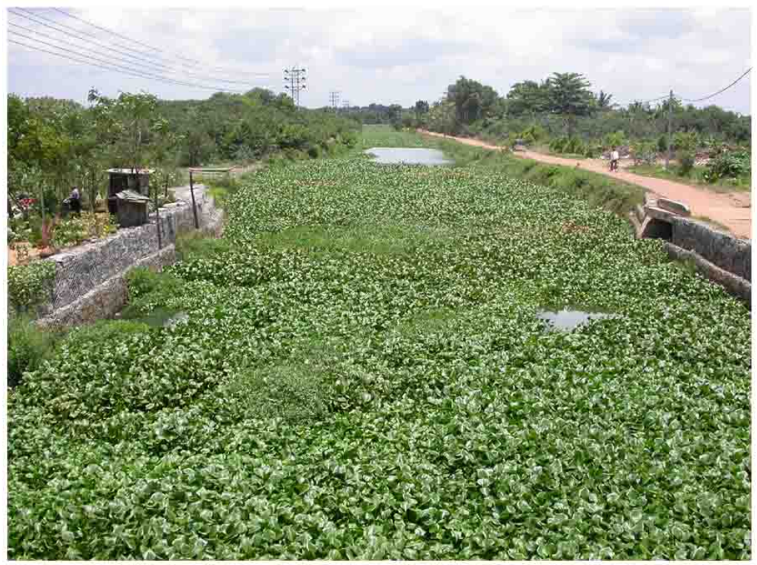

Fig 05: Water covered with invasive aquatic flora

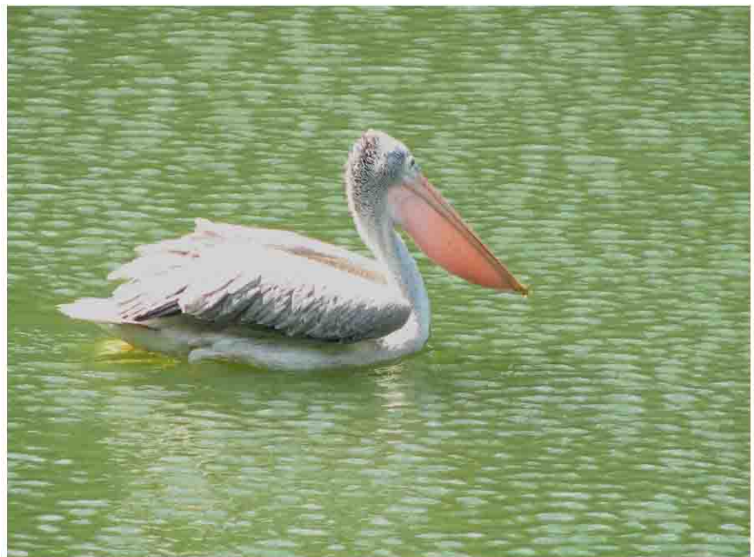

Fig. 07: Spot-billed pelican (Pelecanus philippensis)

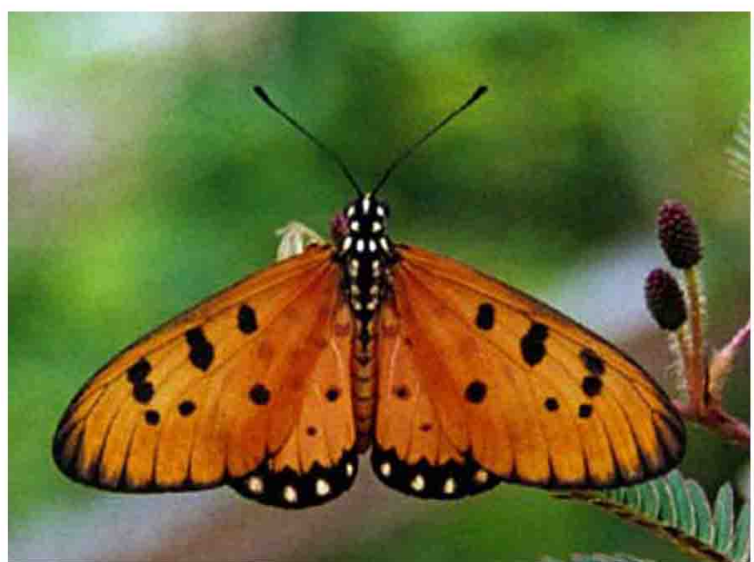

Fig. 09: Tawny costor (Acraea violae) 